KLEINE TEXTE FÜR VORLESUNGEN UND ÜBUNGEN HERAUSGEGEBEN VON HANS LIETZMANN

84

\title{
AUS EINEM
}

\section{GRIECHISCHEN ZAUBERPAPYRUS}

von

RICHARD WÜNSCH

BONN

A. MARCUS UND E. WEBER'S VERLAG

I9II 